\title{
IS SOCIAL WORK A PRIORI HUMANE IN ITS NATURE?
}

Keywords:

Social work; humanism; humanistic social work; humanistic values of social work; globalisation.

Author:

Dr. Milosav Milosavljević is Full Professor of the Social Work at the University of Belgrade.

\section{Correspondence:}

milosav.milosavljevic@gmail. com

Field:

Social work

DOI:

10.5937/politeia0-21862

Paper received on: 03.04.2019.

Paper accepted for publishing on: 12.05.2019.

\section{Summary}

Social work is an activity and profession that has passed through various phases in its development, taking on different forms (traditional-positivist, functionalist, bureaucratic, radical). The character of social work can be judged on the basis of what its goals are, on which values and principles it is founded; what its relations towards citizens, service users, colleagues, and members of related professions and local communities are, as well as on the basis of means, methods, and skills it uses in its practice.

At the beginning of the 21st century, social work follows the pluralism of ideas, concepts, models, experiences, and practices, as well as it faces new and complex challenges and problems arising from the processes of globalisation and diversification, as generally complex processes in their nature, which, in turn, create even more complex social problems, but, at the same time, narrow down institutional, economic, political, and cultural opportunities for social work.

The author claims that there are solid ideological and value bases, ideas, theories, and good practice experiences for the development of humanistic or integrative social work, but their realisation depends on the economic, political, cultural, and social context of concrete societies, and on the will and power of social workers to establish their work on humanistic grounds.

It is the general conclusion of this paper that social work is not humane a priori, which means that we still need to create such social conditions in order to direct goals, contents, methods, procedures, and attitudes of social work towards the affirmation, well-being and welfare of human beings in practice. 


\section{INTRODUCTION}

The general question is whether some systems, institutions, and professions are automatically humane due to the fact that they are dealing with man? If that were absolutely true then medicine would be an ideal model of humane activity. But is this always true? There are examples of numerous abuses of medicine for political and other purposes, such as experiments in vivo in Nazi Germany camps, or so-called voluntary examination of new drugs, or LSD experiments on students in the US, the use of war poisons, psychological warfare and depleted uranium, etc. These and similar activities have been carried out in the past and are still practiced today by some of the most skilled members of medical and related professions.

In the spirit of the previous general question, another question arises: Is social work automatically humane due to its task of meeting social needs and overcoming people's personal and family problems? Different reactions can be expected on this issue; most social workers will consider this issue redundant, some respond with a sharp dismissal; public opinion could be divided, and many, if not most users of social work services, will come up with a number of reasons why there is no such automation in reality. The answer to this question is not simple, nor universal. One, therefore, must have in mind a concrete time, social context and space in which social work takes place. On the other hand, possible answers should be based on concrete analyses of the principles and values on which social work is based; the goals it serves; attitudes towards people, and not abstract, but concrete citizens, and on the content, tools and methods used in practice. In summary, the essen- tial answer lies in the assessments of whose interest's social work is serving: governing structures, social workers or service users.

The aim of this paper is to summarily answer the question posed in the title using historically based analysis of the social context, the practice of social work and, in particular, the mutual relations of social workers and users of their services.

\section{HISTORICAL CONTEXT}

In a historical context, it should be recalled that social work as an activity was created in the second half of the $19^{\text {th }}$ century on the principles of bourgeois philanthropy and mercy and on the general idea of the capitalist society as the most humane in the overall history of civilisation. It relies on the belief in natural selection and the general well-being of man, as well as the ability to return, with appropriate support, to the usual and desirable flows of society, all those who leap from the values and normative systems of a prosperous society, offering equal opportunities to all.

Naturally, the initial activity of social work takes place through various forms of voluntary association and organisation and is especially massive in the most developed capitalist states, in which, in nature, the first mass social problems manifest themselves most clearly. It is no coincidence that among the volunteers of the philanthropic associations, women from middle class families were more massively represented, as this was part of the social status and reputation, as well as students, who were also members of higher or middle classes.

Social work as a profession arises from the clear knowledge that growing social problems overcome the power of welltrained volunteers and voluntary organisa- 
tions. Moreover, the problem of motivation, retraining and engagement of volunteers was constantly present in relation to the huge increase of those who needed social support and assistance. Social work as a professional activity is created at the end of the XIX century, basically on the idealistic idea that the state can overcome social problems using scientific knowledge and specially trained volunteers, paraprofessionals and professionals. In fact, it is a practical need of a capitalist society for social control of an increasing part of poor and other marginalised sections of the population.

Two segments follow social work, since its creation: ideas and concrete practices (Payne \& Askeland, 2008: 2). Ideas are expressed through goals and principles, later through models, concepts and theories, and practice through content, tools and methods. History shows that these two segments of social work often do not go together, that they are sometimes in discrepancy and that each follows some of its own path. The reason for this should be sought in the social context, decision-makers, business owners and power relations, as well as in the interests of those involved in complex processes of social work (Milosavljević, 1998: 42-43).

Although social work and sociology occur at similar times, with related goals, sociology to learn and explain the nature of social problems, and social work to deal with their consequences, the ideas of social work originate from developed sciences (medicine, biology, psychology, education, law, etc.), while practice relies on experiences, methods and techniques of the profession, which is largely present today.

Social work has gone through several general phases in which some of its key paradigms, principles and goals have been changed. The first phase could be characterised as traditional-positivistic and lasted almost until the half of the $20^{\text {th }}$ century. In short, social work is based on positivist ideas about an ideal capitalist society, based on work, order and social order, the existence of universal values and the usual ways of individuals' behaviour, who are controlled by social institutions, due to the superiority of society in relation to the individual.

It is visible that social work, which some call "correctional" serves in practice to preserve order, the system and social peace. It primarily deals with the re-socialisation, rehabilitation and reintegration of the poor, marginalised, the deviant, and the large mass of immigrants in the United States, especially from Europe. Social work dominantly deals with unadjusted, poor, deviant and marginalised individuals and families. In accordance with the ideas of individualisation, the most social work with the individual is represented, and only partially, social work with the group, most often with the family.

The institutional framework of social work consists in the most merciful and other volunteer organisations and local social services. In methodical terms, social work mostly uses methods and techniques of medicine, especially psychiatry, pedagogy and psychology. In literature, this type of social work is often referred to as "medical", not only because the first professionals in the United States were employed and trained in some psychiatric institutions, but also due to terminology and methods used. Citizens referring to social work help were designated as clients.

Modernism in the concept of value is based on the principles of pluralism, diversity and connections between systems and subsystems, especially in society and social 
structures. The ideal-type framework of social work is a welfare state model, which some have labeled as "the night guard of capitalism". The practice of the state of well-being was possible on the basis of the global distribution of world wealth between rich and poor countries and on the basis of controlled and targeted redistribution within national wealth.

In the institutional sense, in the United States, besides volunteers, public social services (state programmes for the poor and local social services) are being developed, while volunteering and the development of non-governmental organisations are stimulated in Europe.

Pluralism in social work is first seen in a multitude of ideas, paradigms and theories, as in the development of specific approaches, concepts, institutional frameworks and the diversity of methods, techniques, skills and practices of social work. In addition to social work with the individual, various models and practices of social work are developed with groups and social work in the community.

The pluralism of services and the promotion of the development of diverse social services on the principle of individualisation contribute to the development of various specialisations in social work. In order to harmonise the practice and position of users, but also for the safety of social workers, different service standards are being created and introduced, which is also true for their training and improvement programmes. Social work also develops in former colonies and some socialist and post-socialist countries. In this case, there is a noteworthy "imperialism" of social ideas and experiences that are spreading in these new areas thanks to literature, uncritical use of social work education programmes, visiting pro- fessors, studying candidates from the United States, the United Kingdom, etc.

The concept and practice of a welfare state were equally sharply criticised since the 1970s from the perspective of different ideological, political and theoretical perspectives and with different motivations. Thus, from the perspectives of conservative prospects, the state of well-being is blamed for economic and social crises, the growth of poverty and unemployment, the passiveness of citizens, and the creation of non-workers and addicts of social benefits, and, in particular, due to high social costs without corresponding social and economic effects.

When it comes to radical and critical attitudes, they are best illustrated by the view that social work is an agent of resocialisation, of compensation, of oppression and a disciplinarian agent (Hollstein and Meinhold, 1980: 141).

Neo-liberalism and globalisation have ruined, not only concepts, but also the practice of the welfare state, although it has survived in certain segments in some European countries. Regardless of the fact that in the last instance the function of the state of welfare was social control and the preservation of the capitalist system, it gave way to the development of various authentic segments of social work and the possibility of its self-identification and recognition by the citizens.

Postmodernism is an old term first developed in art and architecture, and then in philosophy, sociology and other sciences. It is, in fact, a set of diverse ideas (philosophical, sociological, ideological, economic, political, etc.) that cannot be consistently and comprehensively analysed and presented. Since the word "postmodernism" is used here as a contextual framework for 
understanding contemporary social work, here we will list only some of its characteristics, more precisely, ideas and settings of importance for contemporary social work. Such essential assumptions could be the following:

- Relativity and subjectivity of experience, scientific truth and morality;

- Rejection of methodological and theoretical conventions and principles;

- The dominance of the economy over all other social spheres;

- Bourgeois Market laws and Market as measures of all, even individual values, and regulator of all social relations;

- Power and hunger for information and their use in manipulating people and creating a lifestyle;

- The importance of the private sphere is emphasised not only in economic but also in micro social relations;

- The disproportionate power of the owners of international capital in relation to all other structures of society and in the overall international relations;

- Equalisation of knowledge and politics, etc.

\section{GLOBALISATION AND DIVERSIFICA- TION AS A SOCIAL CONTEXT}

Generally speaking, the overall sphere of all social relations takes place between opposing processes: globalisation and diversification and uniformisation and pluralism. Usually, globalisation is linked to the process of opening up and liberalising national financial markets and creating a world capital market. However, bearing in mind the economic and social aspects of globalisation, first of all, it can be said that this is a process of unavoidable movement of capital, labour, products, technology, values and ideas around the world in an apparently free and spontaneous way.

Some authors consider that globalisation is the result of the development of science, modern technology, market economy and democracy, which, basically, is not incorrect. However, globalisation essentially means the process of spreading neo-liberalist ideas, models and practices around the world. These are complex processes that, by the force of economic, political and military power, are established throughout the entire planet, as the basis for new economic, social, political and other relations in the modern world, which some designate as a new world order. The power of the bearers of globalisation is so great that individual, largely unrelated, resistances soon appear as indicators of the inevitability and irrepressibility of this universal tendency in overall relations within the contemporary world, but rather as a different view and exit from complex economic, political and social relations and problems with which most of the countries and population meet.

As one famous author writes, "Globalisation is not simply a market-driven economic phenomenon. It is also a very large, political and ideological phenomenon ... Thus, globalisation must be understood as a transnational ideology of neo-liberalism that seeks to establish its domination around the world" (Mishra, 1999: 7).

The UN Development Programme (UNDP, 1999) identified four structural changes affecting socio-humanitarian institutions at the beginning of the 21st century:

- New global market in services such as banking, insurance and transport, and especially unregulated financial 
markets and global consumer markets.

- New actors such as multinational companies (which integrate production and marketing), the World Trade Organisation, the International Criminal Court, international non-governmental organisations, regional economic blocs and policy coordination between countries with special interests, such as the OECD, G7, G8 or G10.

- New rules and norms such as market economy policy, human rights conventions, global environmental conventions and multilateral trade agreements.

- New communication tools such as the Internet, simultaneous connection of more people by e-mail, cellular (mobile) telephone, fax machines, fast and inexpensive air traffic and computer design.

Economic interests and goals make the core of globalisation, while others can be said to be indirect. The emergence and functioning of multinational companies and multinational capital have bothered the market and other borders, as well as the sovereignty of individual states. It was necessary to provide free space for circulation of capital, labour, goods and technology worldwide, according to the needs and interests of the owner of the capital. The institutional framework of economic globalisation has been created through international documents and contracts, international financial institutions and the world stock and equity markets.

Concerning the social aspects of globalisation, as we already wrote, “ In a conceptual sense, the key notion and conviction of globalists is that a good market economy is the key to all the economic and social problems of the modern world, which rejects the importance and need of social policy, with the exception of certain international poverty reduction projects, especially in underdeveloped countries...representatives of neo-liberalist ideas in the social sphere insisted on the principles of individual responsibility for social security and status, as well as on personal choices and freedom and self-help, as a way of overcoming personal and family problems" (Milosavljevic, Petrović, 2017: 260).

The principle of the redistributive justice of the welfare state is replaced by the principle of subsidiarity and individual choice and responsibility. On the other hand, radical options insist on empowering individuals and their various communities, self-help, self-actualisation, as well as participation in decision-making about the social needs and problems of individuals, social groups or communities.

In the neo-liberal model of social relations, social rights are separated from the sphere of labour, so that they are viewed as part of the overall civil rights. Social security and status are gaining in different markets (capital, labour, goods and services) and are the result of self-realisation, self-actualisation and self-responsibility of all subjects in economic, political and social relations, which is in line with the ideology of individualism.

Diversification, as apparently opposed to the process of globalisation, only partly means the establishment of diversity within the contemporary world, which would make it apparently rich in many aspects. Globalisation follows the uniformisation and imposition of ideas, principles, standards and life style of Western societies. In essence, diversification here means creating even greater differences between developed and underdeveloped countries, between rich and 
poor, both internationally and nationally, between the minority of the powerful and the majority of the impotent.

According to two authors: "The application of the principles of a market economy in the social sphere has led to the creation of the so-called mixed economy of welfare. In essence, on a property plan, this means the privatisation of a large part of the state and public social sector. In business and market terms, this means competitiveness and legal equality of the public, private and voluntary social services sector in addition to a market match, which should ensure that the highest value for money, efficiency, greater responsibility, money spent and better quality of service."

On the other hand, increasing the efficiency and effectiveness of social services and productivity in the social sphere is linked to the expansion of entrepreneurship and a different way of managing social services. In this sense, two apparently opposite tendencies appeared. One is labeled as neo-taylorism and refers to the good, adaptable and organised structure of those offering social services and programmes on the market, strengthening control, regulating the attitude of actors in the social sphere and supervising delegated institutions and power representatives. The second tendency is referred to as social non-sense and based on the ability to predict, flexibility, adaptability and rapid response to changes in the social market, self-control, skills development and team work. (Sewpaul, Hölscher, 2004).

In such a social context, users of services and support of social work are those individuals, families and social groups who are unadjusted and unprepared for the overall social game, in short, the numerous and varied victims of globalisation. As Stiglitz, a former leading economist at the World Bank and Nobel Prize Winner wrote: "Globalisation as a powerful force has brought huge gains to some. Thanks to the way it was, however, millions did not enjoy its benefits until the situation of more than a million people worsened. Poor nations do not have a great choice in decision-making, while international economic agencies have imposed their policies favouring the policies and interests of the West." (Stiglitz, 2002: 268).

When it comes to other adverse social consequences of globalisation, the following attitudes are acceptable to us: "There are three main obstacles that prevent full access to human rights and the fruits of social development. These obstacles are poverty, discrimination and lack of education ... Poverty is a violation of human economic rights - the right to adequate income necessary for sustaining ... Discrimination means the categorisation of people denying complete access to human rights based on belonging to a category based on sex, gender, ethnicity membership, race, caste, social class or other categorisation ... Lack of education is a much wider problem than many of us think: without education, an individual is not only trapped in poverty, but exposed to many other risks" (Mapp, 2008: 23).

In a similar spirit to the social consequences of globalisation, both Payne and Askeland point out: "Among the most important consequences of the development of post-modern, globalised social work is facing inequalities within and between societies, because inequalities create social tensions between different groups and psychological stresses for individuals. Social work is devoted to social justice. Our experience as social workers dealing with individuals and small groups directs us to 
address the impact of the social in a person. Social work that deals only with psychological problems fails to cope with the consequences of injustice and inequality as well as social factors that lead to problems. Social processes that create inequality and injustice are constantly changing. This means that practice and education should be aware of inequalities created by new social trends in order to understand how they affect individuals and communities." (Payne, Askeland, 2008: 2)

In the institutional and structural sense, globalisation and the acceptance of the principles of neo-liberalism in the social sphere have led to deinstitutionalisation, which most often means the abolition and reduction of the number of social and related institutions in which social work is the dominant activity, the privatisation of a significant part of social services and jobs and the expansion of the non-governmental sector in the sphere of social services. Although, in these circumstances, the multiplication and expansion of the opportunities for a wide range of competitive social services is indicative of the experience, they say that the changeover paid the price to the most vulnerable and the most extreme, and that the pluralism of services conditioned by market principles only reduced access to the same large part of the population, while the abolition of social programme's conditions of life are further in jeopardized. There are also indications that many social workers have paid for these changes, not primarily because of their inability to adapt to these fundamentally different conditions and requirements, but because they have lost their jobs. In this regard, in addition to the aforementioned general problems, the circumstance is very unfavourable that in most countries, and especially in the rich countries of the West, social work is mostly a part of the state, and reduced largely to an organized social assistance provision. It is similar to social services offered by profit-making or non-profit organisations, as they are largely financed by states.

Regarding globalisation from the perspectives of social work, the question is whether Western concepts, models of practice, social work organisation and education for this profession are universal (global) in their application? Experiential records of social work tendencies and the particular work of the International Federation of Social Workers and the International Association of Schools of Social Work are increasingly questioning dominant Western ideas, concepts and practices of social work. New experiences and ideas are needed equally in the countries in which it has emerged and is the most developed, as well as in the areas in which it is still in the infancy. It is expected, moreover, to backwardly impact the ideas and experiences of other societies on social work in the West. However, the question is how fast these changes can happen, bearing in mind the economic, social and cultural power of many Western monopolies.

\section{CAN THE SPIRIT OF HUMANITY INSPIRE SOCIAL WORK?}

The answer to this question requires a careful analysis of the concrete practice of social work in different countries and areas of the world. However, the realisation of the principles and objectives of social work depends on economic, political, social, cultural and other conditions in each particular country.

It can be said that for the emergence of 
humanistic social work there are conceptual and principled assumptions defined, among other things, in the documents of the International Federation of Social Workers and the International Association of Schools for Social Work:

"Social work is a practice-based profession and academic discipline that promotes social change and development, social cohesion, and the empowerment and liberation of people. The central principles of social work are social justice, human rights, collective responsibility and respect for diversity. Based on the theories of social work, social sciences, humanistic and autochthonous knowledge, social work engages people and structures to focus on life's challenges and increasing well-being. This definition can be extended at national and/or regional levels." (IFSW, 2016).

In this spirit, the emancipator character of social work is emphasised, which implies its engagement in empowering and liberating people. It comes from the knowledge that structural barriers contribute to the reduction of inequality, discrimination, exploitation and oppression. The development of critical awareness through a reflection on structural sources of oppression and/or privilege based on criteria such as race, class, language, religion, gender, disability, cultural and sexual orientation and the development of strategies for action against structural and personal barriers are central to emancipator practice. From this point of view the central goal of social work is the incitement and implementation of social changes based on the assumption that social work interventions occur when assessing that the current situation whether at the personality level, family and smaller groups, communities or societies - requires a change or development. This obligation of social work is based on the need to challenge and change the structural conditions that contribute to marginalisation, social exclusion and oppression. Social change initiatives recognise the place and role of human activities in the promotion of human rights and economic, ecological and social justice (Milosavljević, Petrović, 2017: 35-36).

Social work also contributes to the maintenance of social stability, unless stability is used to marginalise, exclude or oppress any particular group of people. Humanistic social work participates in the promotion of social development in terms of intervention strategies, desired outcomes and policy frameworks, whereby the development framework is added to a more popular residual and institutional framework. In the most general sense, here the notion of humanity is derived from some special characteristics of a man that distinguish him from other living beings, such as rational thinking, purposeful and thoughtful work, imagination, immense abilities and options of creativity, spirituality and emotion, for new and especially for respect and understanding of other people, their needs, interests and specialties. Bearing in mind the different levels of man's creativity, it can be assumed that humanity, or inhumanity as an antipode, is fortunate in human ideas and thoughts, in their spiritual creations (culture, religion, science, politics, law, etc.) Particularly important is the idea of humanity embodied in everyday and concrete practice.

On the other hand, the basis of modern humanism, which is the result of the long tradition and free thoughts and actions of numerous thinkers, artists, scientists and other spiritual creators, are stated in the Declaration of the World Humanist Con- 
gress in the following way:

- Humanism is ethical, which means it affirms the wealth, dignity and autonomy of the individual and the right of every human being to the fullest possible freedom compatible with the rights of others.

- Humanism is rational, which means it strives for the use of scientific creativity and not destructiveness.

- Humanists believe that solutions to world problems lie in human thought and action rather than in divine intervention.

Humanists also believe that the application of science and technology must be conveyed to human values. Science gives us the means, but human values must determine the goals.

- Humanism supports democracy and human rights.

- Humanism insists that personal freedom must be combined with social responsibility.

- Humanism is a response to the widespread demand for an alternative dogmatic religion.

- Humanism values artistic creativity and imagination and recognises the transforming power of art.

- Humanism is a lifestyle that strives for the maximum possible accomplishment by fostering ethical and creative life and to offer an ethical and rational means of directing ourselves to the challenges of our times.

- Humanism can be a way of life for everyone and everywhere. (World Humanistic Congress, 2002).

The answer to the question of whether social work in the concrete practice of some states, regions or local individuals requires, among other things, the analysis of its following characteristics: the goals of social work; the values and principles on which it rests; orientation (to whom it serves) and content, methods and skills used in practice. The main goal of social work is to use social knowledge, human thoughts, actions and experiences of good practice to meet social needs, improve well-being and provide special assistance to the impotent, vulnerable, and marginalised. The particular general goal of social work is to reduce various types of social inequality and to achieve the principles of social justice and human rights. Among the principles of humanistic social work, we emphasise here the exceptional importance of the principle of liberation, which refers simultaneously to the efforts of social work to create conditions for human self-realisation and expression in all its human dimensions and characteristics (creativity, work, love, readiness to the initiation of change and self-change and improvement), but also the liberation from various disorders, frustration, deprivation, delusion and impotence; the principle of equity means, above all, the creation of conditions for the equal access to social services under the same conditions for all citizens, as well as the application of the principle of providing support and services according to the criteria of urgency, severity and levels of social vulnerability or risk; the principle of creativity, contained in the requirement that every need, problem or social change rests on thinking, planning, organising and engaging, without improvising and experimenting with people; professional imagination, which is related to social efforts and is the best way to escape from the "idiocy of paper and unproductive work", illusions and improvisation and professional respon- 
sibility in performing the roles and tasks of social workers and in relations with colleagues, members of others vocation and in nurturing and preserving the reputation of the social work profession.

Social workers relation to individuals, families, groups and local communities to whom social services are provided should be based on the requirement for social workers to stop users of their services, observing as objects and passive participants, unwilling to participate in changes in their own social situation or in overcoming the life problems they encounter. At the same time, it means that changing social workers' attitudes towards people, groups and communities that need their services should be directed towards transforming users of services into subjects, accomplices and co-responsibles for all actions and activities that address social needs, problems or the situation for which they are referred to do social work. It is important that human rights and freedoms are also based on the subjectivity and social responsibility of citizens, including those who are particularly vulnerable to social exclusion.

Humanity in social work relates to the idea that man is the highest possible value in itself. Of course, a man appears here in a dual general social role: first, as a goal and value for himself, and then as a carrier of well-being, happiness, welfare and responsibility for his own destiny, but not isolated and alienated, but united, with other people, whose freedoms, rights, security and perspectives are indivisible and inseparable.

In other words, social work, which starts from this key principle, respects at the same times the universal potential creative power and the existential essence of man (the diversity of his roles, dimensions and characteristics, including the right to diversity).
All in all, it can be concluded that social work is not a human a priori, which means that the social conditions have yet to be created so that it can focus on its affirmation, well-being and welfare of people in practice with its goals, contents, methods, procedures and devotion. It can also be said that there is a conceptual and theoretical basis, but not real economic, political and social conditions, and that this will be a difficult and long-lasting struggle. The present and the future bring social work to many challenges, but also the difficulties and obstacles for which new, creative and original solutions are needed. Existing experiences can be a good but inadequate transfer for its success and affirmation. The idea is that social workers are to make the most of them for the benefit of those they are supposed to serve: people, their families and communities. Only those social workers whose service users are happy.

\section{REFERENCES:}

Hollstein, W. \& Meinhold M. (1980). Socijalni rad u kapitalističkim produkcionim uslovima. Beograd: Viša škola za socijalne radnike Beograd, Viša škola za socijalne radnike; Zagreb: Zavod za proučavanje socijalnih problema Beograd, Institut za socijalnu politiku, Viša škola za socijalne radnike; Skoplje: Jugoslovenska konferencija za socijalne delatnosti.

Howe D. (1994). Modernity, postmodernity and social work. British Journal of Social Work, 24.

Howe, D. (2003). Uvod u teoriju socijalnog rada. Beograd: Fakultet političkih nauka, Naučno-istraživački centar za socijalni rad i socijalnu politiku. 
IFSW (2016a). Global Definition of Social Work. URL: http:// ifsw.org/policies/definition-of-social-work, pristupljeno 21.03.2019.

IFSW (2016b). The Global Agenda for Social Work and Social Development. URL: http:// ifsw.org/get-involved/agenda-for-socialwork/, pristupljeno 20.03. 2019.

Mapp, S. C. (2008). Human Rights and Social Justice in a Global Perspective. Oxford: Oxford University Press.

Milosavljević, M. (1998). Socijalni rad na međi vekova. Beograd: Draganić.

Milosavljević, M. (2010). Osnove nauke socijalnog rada. Banja Luka: Filozofski fakultet.

Milosavljević, M., Petrović, J. (2017). Uvod u socijalni rad. Banja Luka: Fakultet političkih nauka.

Mishra, R. (1999). Globalisation and the welfare state. Cheltenham, Northampton: Edward Elgar.

Payne, M. (2011). Humanistic Social Work. Basinstoke: Palgrave Macmillan.

Payne, M. \& Askeland, GA. (2008). Globalization and International Social Work. Aldershot: Burlington Publishing.

Sewpaul, V. \& Hölscher, D. (2004). Social work in times of neoliberalism - A postmodern discourse. Pretoria: Van Schaik Publishers.

Stiglitz, J. E. (2002). Globalization and Its Discontents. London: Penguin books.
World Humanistic Congres (2002). "The Amsterdam Declaration 2002". URL: https:// humanists.international/what-is-humanism/the-amsterdam-declaration. pristupljeno 20.03.2019. 


\section{ДА ЛИ ЈЕ СОЦИЈАЛНИ РАД А РRIORI ХУМАН?}

Кључне ријечи:

Социјални рад; хуманизам; хуманистички соицијлни рад; хуманистичке вредности соиијалног рада; глобализација.

Ayтop:

Др Милосав Милосавлевић је редовни професор соиијалног рада на Универзитету у Београду.

Коресподенција:

milosav.milosavljevic@gmail. com

Област:

Социјални рад

DOI:

10.5937/politeia0-21862

Датум пријема чланка: 03.04.2019.

Датум прихватања чланка за објављивање: 12.05.2019.

\section{Сажетак}

Соицјални рад као делатност и професија пролазио је кроз различите фазе у свом развоју, попримајући разноврсне борме (традиционално-позитивистички, функиионалистички, бирократски, радикални). О карактеру соиијалног рада може се судити на основу показательа о томе: који су негови ицлеви; на којим вредностима и приниипима је утемелен; какав је юегов однос према грађанима, кориснииима услуга, колегама и припаднииима сродних професија и локалним заједниизама и којим средствима, методама и вештинама се користи у пракси.

На почетку XXI века соиијални рад прати плурализам идеја, кониепицја, модела, искустава и праксе, али и нови и сложени изазови и проблеми који извиру из проиеса глобализаиија и диверзификације, као општих сложених проиеса, који, углавном стварају додатне сложене социјалне проблеме, али сужавају институиионалне, економске, политичке и културне могућности соиијалHог рада.

По миштену аутора, постоје добре идеолошке и вредносне основе, идеје, теорије и искуства добре праксе за развој хуманистичког, или интегративног соиијалног рада, али да ће юегово оствариване зависити од економског, политичког, културног и социјалног контекста конкретних друштава и од воле и моћи соиијалних радника да своје делане успоставе на хуманистичким основама.

Општи је закључак овог рада да соиијални рад није а прирори хуман, што значи да тек треба да се стварају друштвени услови да се он својим иилевима, садржајима, методама, поступицма и одлносом усмери према афирмаичји, добробити и благостану човека у пракси. 
